\title{
Tema-Tema Penelitian Pendidikan: Inspirasi \& Motivasi bagi Guru Madrasah Ibtidaiyah
}

\author{
Agus Maimun \\ Universitas Islam Negeri Maulana Malik Ibrahim Malang \\ maimun@pai.uin-malang.ac.id
}

DOI. 10.18860/mad.v12i2.8927

Abstract. Research activities are basically part of teacher responsibilities in education. This confirms the statement, the task of the teacher is not only as an educator and teacher, but also as a researcher. As researchers, teachers must have research competencies. This writing will discuss the role of the headmaster in developing a culture of research in Madrasah Ibtidaiyah, the ability of teachers to find research problems that are relevant to their scientific fields in Madrasah Ibtidaiyah, and research space and research themes on education in Madrasah Ibtidaiyah. This paper discusses experiments and empirical practices using the reflective discussion method, which combines telling with deduction thinking with induction. This paper is expected to help teachers or students of Madrasah Ibtidaiyah Teacher Education (PGMI) to more easily find problems or research themes that can be formulated into research titles and can easily conduct research properly. The writing shows that the madrasah headmaster needs to develop a strategic program that allows the growth of a facilitating culture among MI teachers. Research issues relevant to the field of teacher science can be sought and obtained from various sources, published: application of theory, studies that can be replicated, clarification of contradictory findings, literature review, individual experiences, and electronic mailing lists. Many scopes and research themes can be formulated as research titles, published: intracurricular, supplementary curricular, madrasah management, madrasah related, madrasah leadership, education personnel, student issues, and the relationship between madrasa and related relationships. For this reason, something that must be done by policy makers in Madrasah Ibtidaiyah always encourages and facilitates teachers to conduct research. Specific research that makes a significant contribution to improving the quality and outcomes of education and learning.

Keywords. Teacher; Research Culture; Research Problem; Research Theme

Abstrak. Kegiatan penelitian pada dasarnya merupakan bagian dari tanggungjawab guru dalam pendidikan. Ini mempertegas pernyataan bahwa, tugas guru bukan saja sebagai pendidik dan pengajar, tetapi juga sebagai peneliti. Sebagai peneliti, guru harus mempunyai kompetensi bidang penelitian. Tullisan ini akan membahas tentang peran kepala madrasah dalam membangun budaya penelitian di Madrasah Ibtidaiyah, kemampuan guru menemukan masalah penelitian yang relevan dengan bidang keilmuannya di Madrasah Ibtidaiyah, dan ruang lingkup dan tema penelitian pendidikan di Madrasah Ibtidaiyah. Tulisan ini bersifat teoritis dan praktis-empiris dengan menggunakan metode pembahasan reflektif, yaitu memadukan secara jitu antara berfikir deduksi dengan induksi. Tulisan ini diharapkan dapat membantu guru madrasah atau mahasiswa Pendidikan Guru Madrasah Ibtidaiyah (PGMI) agar lebih mudah dalam menemukan masalah atau tema penelitian yang dapat diformulasikan menjadi judul penelitian dan sekaligus mampu melaksanakan penelitian dengan baik. Hasil tulisan menunjukkan bahwa kepala madrasah perlu mengembangkan program strategis yang memungkinkan tumbuhnya budaya meneliti di kalangan guru MI. Masalah penelitian yang relevan dengan bidang ilmu guru bisa dicari dan diperoleh dari berbagai sumber, meliputi: penerapan teori, studi yang dapat direplikasi, klarifikasi temuan yang kontradiktif, review literatur, pengalaman individu, dan electronic mailing lists. Banyak ruang lingkup dan tema penelitian yang dapat diformulasikan menjadi judul penelitian, meliputi: intra kurikuler, ekstra kurikuler, manajemen madrasah, penciptaan suasana madrasah, kepemimpinan madrasah, 


\section{MADRASAH}

Jurnal Pendidikan dan Pembelajaran Dasar

p ISSN: 1979-5599 | e ISSN: 2502-194X

tenaga kependidikan, masalah kesiswaan, dan hubungan madrasah dengan instansi terkait. Untuk itu, sesuatu yang harus dilakukan oleh para pengambil kebijakan di Madrasah Ibtidaiyah adalah selalu mendorong dan memfasilitasi guru untuk melakukan penelitian. Khususnya penelitian yang mampu memberikan kontribusi yang signifikan bagi peningkatan kualitas dan hasil pendidikan dan pembelajaran.

Kata Kunci. Guru; Budaya Penelitian; Masalah Penelitian; Tema Penelitian

Received : 29-05-2020

Approved : 15-06-2020

Revised : 12-06-2020

Published : 17-06-2020

Copyright (C Madrasah Jurnal Pendidikan dan Pembelajaran Dasar. All Right Reserved.

This is an open access article under the CC BY-NC-ND license

(http://creativecommons.org/licenses/by-nc-nd/4.0/).

Correspondence Address: maimun@pai.uin-malang.ac.id

\section{A. PENDAHULUAN}

Kegiatan penelitian pada dasarnya merupakan bagian dari tanggungjawab guru dalam pendidikan. Ini mempertegas pernyataan bahwa, tugas guru bukan saja sebagai pendidik dan pengajar, tetapi juga sebagai peneliti. Sebagai peneliti, guru harus mempunyai kompetensi bidang penelitian. Dengan penelitian pendidikan, guru dapat menggali dan memberikan informasi yang dapat dipercaya mengenai kegiatan pendidikan kepada masyarakat, orangtua, politisi, dan berbagai stakeholders lainnya (Lodiko, Spaulding, Voegtle, 2010: 2). Pernyataan ini memungkinkan guru untuk selalu melakukan penelitian, agar dapat memperluas dan memperkaya keterampilan mengajar mereka dan menempatkan mereka dalam kontak kolaboratif dengan teman sebaya yang memiliki minat yang serupa dalam penelitian. Melalui penelitian, guru akan dapat mengungkap sebab dan akibat suatu peristiwa pembelajaran, apa yang ada di balik sebuah peristiwa dan bagaimana polanya, siapa saja yang terlibat di dalamnya dan mengapa terjadi, bagaimana penyelesaiannya dan dengan cara apa, serta bagaimana seharusnya dan sebagainya. Guru juga dapat mengaplikasikan ilmu-ilmu pengetahuan secara tekstual dan kontekstual dalam pembelajaran. Untuk itu, seorang guru harus mempunyai kompetensi penelitian, disamping kompetensi lapangan, kompetensi dibidang kurikulum, kompetensi tentang belajar seumur hidup, kompetensi dibidang sosial-budaya, kompetensi emosional, dan kompetensi dibidang informasi komunikasi (Selvi, 2010: 168-169).

Kompetensi penelitian mencakup kompetensi metode dan teknik penelitian, merancang, dan melaksanakan penelitian di bidang pendidikan dan pembelajaran. Kompetensi penelitian berpengaruh bagi guru dalam meningkatkan kualitas pembelajaran, agar pembelajaran lebih efektif, efisien, dan menyenangkan. Disamping itu, kompetensi penelitian guru sangat penting bagi siswa untuk mendapatkan pemikiran ilmiah dan keterampilan proses ilmiah yang aktual dan kontekstual. Kompetensi penelitian membantu untuk meningkatkan semua kompetensi guru dan mendukung pendidikan guru berbasis penelitian yang merupakan pendekatan baru dalam pendidikan guru (Selvi, 2010: 170; Niemi \& Sihvonen,2006: 36-37).

Kompetensi penelitian bagi guru, sudah sejak lama digagas oleh para ahli pendidikan. Gagasan ini kemudian masuk dalam salah satu sepuluh kemampuan dasar 
mengajar guru. Kompetensi atau kemampuan yang nomor 10 (sepuluh) adalah memahami prinsip-prinsip penelitian dan menafsirkan hasilnya untuk keperluan pendidikan dan pembelajaran (Uno, Umar, Panjaitan, 2014: 159; Sardiman, 1986: 162). Secara lengkap, 10 kompetensi mengajar guru adalah menguasai bahan pembelajaran, mampu mengelola program belajar-mengajar, mampu mengelola kelas, menggunakan media dan sumber belajar secara efektif dan efisien, menguasai landasan kependidikan, mengelola interaksi belajar-mengajar, menilai prestasi belajar, mengenal fungsi dan layanan bimbingan penyuluhan, mengenal dan menyelenggarakan administrasi sekolah, dan memahami dan mampu menafsirkan hasil penelitian guna keperluan pembelajaran (Mudlofir, 2013: 75). Kompetensi ini kemudian disimplikasi menjadi 4 (empat) kompetensi dalam PP 74 Tahun 2008 Tentang Guru, yaitu kompetensi personal, kompetensi pedagogik, kompetensi profesional, dan kompetensi sosial. Secara eksplisit, kompetensi penelitian masuk dalam kompetensi profesional (Arikunto dalam Sutikno, 2011: 5). Ini menunjukkan bahwa, tugas guru bukan saja sebagai pendidik dan pengajar, tetapi juga peneliti, atau sering disebut juga dengan gurupeneliti (Hopkins, 1985).

Berdasarkan penelitian Sutikno bahwa frekuensi guru dalam melakukan Penelitian Tindakan Kelas (PTK) dan penulisan artikel di jurnal serta penulisan buku ajar sekolah dalam kategori kurang (Sutikno, 2011: 11). Ini menunjukkan bahwa masih banyak guru yang kurang memiliki research ability (kemampuan meneliti) serta research experience (pengalaman meneliti), meskipun dia sudah mendapat tugas atau kepercayaan untuk mengajar siswa cukup lama. Hal ini juga terbukti dengan masih banyaknya guru yang tidak mempunyai karya monumental sebagai hasil penelitian. Seringkali kesulitan yang dialami oleh guru untuk melakukan penelitian adalah menemukan masalah atau tema penelitian yang relevan dengan kebutuhan riil di sekolah atau kelas. Kemudian menuangkan masalah atau tema itu dalam judul penelitian, menyesuaikan judul dengan bidang keahliannya, termasuk jenis penelitian yang perlu dipilih, bagaimana merumuskan permasalahan yang jelas untuk diteliti, metode pengumpulan dan analisis data apa yang digunakan, serta bagaimana melaporkannya (Bawani, 2016: 88-89).

Pada lembaga pendidikan madrasah, kelemahan seperti itu juga terasa. Kondisi bisa dilihat dari belum banyak penelitian yang dihasilkan oleh guru madrasah mendapat tanggapan yang memadai oleh berbagai pihak, bahkan oleh Kementerian Agama sendiri. Banyak penelitian yang secara kuantitatif maupun kualitatif dilakukan hanya untuk memenuhi syarat minimal administrasi untuk memperoleh kredit kenaikan pangkat, bukan sebagai panggilan jiwa dalam rangka mengungkap masalah dan memecahkan masalah, sehingga hasil penelitian tersebut meskipun tergolong baik, namun kurang dapat dibanggakan dalam kerangka pengembangan keilmuan.

Untuk itu harus diakui bahwa, kekurangmampuan guru madrasah dalam meneliti akan berdampak negatif bagi perkembangan keilmuan dan lebih-lebih pada peningkatan kualitas kelembagaan, pendidikan, dan pembelajaran. Penelitian kecil yang dilakukan oleh beberapa guru untuk kenaikan pangkat menunjukkan bahwa banyak di antara hasil penelitian itu memiliki kelemahan, baik di bidang metodologi, isi, maupun kejelasan komunikasi. Jadi idealnya, madrasah harus selalu menggalakkan penelitian bagi seluruh guru untuk memenuhi fungsinya sebagai pelaksana kegiatan keilmuan. Persoalan dana seharusnya tidak lagi menjadi kendala bagi guru-peneliti, sebab sekarang ini banyak madrasah yang mengalokasikan dana untuk membiayai 


\section{MADRASAH}

Jurnal Pendidikan dan Pembelajaran Dasar

p ISSN: 1979-5599 | e ISSN: 2502-194X

P a g e | 121

penelitian. Persoalannya sekarang adalah bagaimana peran kepala madrasah dalam membangun budaya penelitian di Madrasah Ibtidaiyah? Bagaimana guru mampu menemukan masalah penelitian yang relevan dengan bidang keilmuannya di Madrasah Ibtidaiyah? dan, apa ruang lingkup dan tema penelitian pendidikan di Madrasah Ibtidaiyah ? Persoalan inilah yang akan dicari jawabannya dalam tulisan ini dengan mengidentifikasi beberapa masalah dan tema penelitian yang dapat dikembangkan di MI, baik secara eksplisit maupun implisit. Kajian ini bersifat teoritis dan praktis-empiris dengan menggunakan metode pembahasan reflektif, yaitu memadukan secara jitu antara berfikir deduksi dengan induksi (Kasiram, 1993). Tulisan ini diharapkan dapat membantu guru madrasah atau mahasiswa Pendidikan Guru Madrasah Ibtidaiyah (PGMI) agar lebih mudah dalam menemukan masalah atau tema penelitian yang dapat diformulasikan menjadi judul penelitian dan mampu melaksanakan penelitian dengan baik.

\section{B. PERAN KEPALA MADRASAH DALAM MEMBANGUN BUDAYA PENELITIAN DI MADRASAH IBTIDAIYAH}

Salah satu tanggungjawab kepala madrasah adalah melahirkan pemikiran strategis untuk meningkatkan kualitas guru dan personil lainnya. Tanggungjawab ini harus diwujudkan dalam program secara strategis dan realistis yang mampu memberikan semangat bagi para guru dan personil lainnya untuk meningkatkan kualitas diri. Sebagai bentuk tanggungjawab institusional, peran kepala madrasah sekarang dihadapkan kepada tantangan, agar madrasah mampu menjadi ummatan ilman. Implikasinya adalah tumbuhnya budaya akademis, bagaimana agar guru mempunyai motivasi penelitian yang tinggi dan penelitian yang dilakukan guru dirasakan relevan dalam peningkatan kualitas pembelajaran yang hasilnya prestasi belajar siswa semakin meningkat. Disinilah pentingnya guru dalam menemukan tematema penelitian aktual dan kontekstual yang bermanfaat kepada masyarakat luas, sehingga mampu merespon perubahan masyarakat yang semakin lama semakin cepat dan komplek yang memerlukan suatu perenungan yang mendalam. Dengan itu guru diharapkan dapat berkembang tingkat kemampuan dan profesionalitasnya. Hasil akhir dari guru yang berkualitas pada gilirannya dapat meningkatkan kualitas lulusan pendidikan, yang berarti juga meningkatnya mutu pendidikan secara nasional (Wahidmurni \& Ali, 2008: 3-4). Penelitian memerlukan semangat untuk selalu belajar dengan banyak membaca dan melihat realitas, agar mampu memanfaatkan teknik dan strategi yang tepat, sehingga dalam melaksanakan penelitian dapat berhasil dengan baik. Keberhasilan penelitian dapat dilihat dari kemanfaatannya untuk pengembangan keilmuan dan kemasyarakatam, serta kemampuan berkompetisi dalam meraih prestasi.

Dengan melihat realitas tersebut, maka upaya kepala madrasah dalam mengembangkan budaya meneliti merupakan suatu keniscayaan di Madrasah Ibtidaiyah (MI). Pengembangan disini harus bermuara pada upaya peningkatan profesionalisme guru. Upaya untuk meningkatkan profesionalitas guru bisa dilakukan dengan dua cara, yaitu dari pihak guru itu sendiri dan pihak luar. Dari pihak guru, dia harus benar-benar mempunyai motivasi, tekad, dan semangat yang tinggi dalam mengabdi dan melaksanakan tugas meneliti untuk memberikan kontribusi yang signifikan pada pengembangan keilmuan dan peningkatan kualitas pendidikan dan 
pembelajaran yang dilakukan di madrasah. Lebih dari itu, para guru harus memiliki kesadaran bahwa profesi guru adalah profesi yang lebih membutuhkan semangat dan tanggungjawab dari seluruh profesi lainnya. Guru yang baik adalah fital bagi kemajuan dan perkembangan madrasah. Peran guru dalam Pendidikan dan pembelajaran tidak bisa digantikan oleh media atau teknologi apapun juga dalam membentuk akhlak siswa (Muhaimin, 2016: 49). Untuk itu, guru harus membekali diri dengan seperangkat kemampuan untuk bisa mendidik dan mengajar serta meneliti dengan baik. Juga kemampuan dalam membangun hubungan yang harmonis dan komunikatif dengan berbagai pihak, khususnya para siswanya (Maimun \& Fitri, 2010:155).

Para guru harus memiliki motivasi intrinsik yang kuat untuk melakukan penelitian. Motivasi ini harus dimanifestasikan pada konsep diri (self-concept) dan citra diri (self-image) yang baik untuk menuju kualitas profesi dan sukses dalam bekerja. Baumeister (1999) mengemukakan bahwa konsep diri merupakan keyakinan individu tentang dirinya sendiri, termasuk atribut orang dan siapa diri mereka itu. Sementara citra diri adalah suatu konfigurasi persepsi seseorang tentang dirinya yang diterima dengan kesadaran atau bagaimana seseorang memandang dirinya secara konkret (Oltmann, Weinstein, Oltmann, 2014 \& Hasan, 1985). Menurut Oltmann, dkk. (2014), ada 6 (enam) dimensi citra diri seseorang, yaitu: dimensi fisik, dimensi psikologis, dimensi intelektual, dimensi ketrampilan, dimensi moral, dan dimensi seksual. Konsep diri dan citra diri seorang guru madrasah sangat menentukan keberhasilan dalam melaksanakan tugas dan tanggungajawab sebagai pendidik dan pengajar, termasuk sebagai peneliti. Namun demikian, untuk membangun citra diri dan konsep diri guru tidak cukup dengan motivasi intrinsik, tetapi perlu didukung dengan motivasi ekstrinsik (Biehler \& Snowman, 1997). Salah satunya adalah dari kepala madrasah.

Kepala madrasah harus berupaya menggairahkan penelitian guru yang difasilitasi oleh lembaga. Kepala madrasah diharapkan berperan secara maksimal dalam memacu guru untuk lebih produktif lagi dalam berkarya. Sebab, berdasarkan pengamatan selama ini, karya penelitian di lingkungan madrasah ini boleh dikata relatif masih miskin. Apalagi sekarang penelitian merupakan salah satu barometer untuk menentukan kualitas atau akreditasi madrasah yang harus mendapat perhatian serius, disamping prestasi lain sebagai barometer keberhasilan madrasah. Untuk itu, madrasah harus dipacu aktifitasnya, agar memprogramkan berbagai kegiatan yang dapat meningkatkan kualitas penelitian guru.

Untuk melahirkan karya penelitian pendidikan yang bagus, maka ada tiga syarat untuk menumbuhkan kepekaan pengamatan dalam penelitian, yaitu: kesediaan untuk membuka diri, mengaitkan dengan gagasan yang terjadi pada umumnya, dan melakukan sedetail mungkin terhadap data dan fakta (Cohen \& Manion, 1994). Data dan fakta inilah yang nantinya akan menjadi dasar dalam melakukan interpretasi terhadap hasil penelitian (Moleong, 1990). Agar kualitas penelitian guru tetap terjaga, maka perlu dilakukan pelatihan penelitian secara berjenjang, sehingga diharapkan hasilnya nampak nyata. Pelatihan penelitian secara berjenjang misalnya mulai pelatihan penelitian tingkat dasar, menengah, dan lanjut. Perbedaan antar jenjang ini terletak pada kajian teorinya dan praktek pengumpulan dan analisis data di lapangan. Untuk memperjelas berbagai konsep dan operasionalisasi penelitian tersebut, maka perlu dibuatkan buku pedoman, agar arah, tujuan, dan sasarannya semakin jelas. 


\section{MADRASAH}

Jurnal Pendidikan dan Pembelajaran Dasar

p ISSN: 1979-5599 | e ISSN: 2502-194X

P a g e

\section{MENEMUKAN MASALAH PENELITIAN}

Pada dasarnya penelitian dilakukan untuk menemukan dan memecahkan masalah. Untuk itu, setiap penelitian yang akan dilakukan selalu berangkat dari masalah, sehingga tanpa masalah, penelitian tidak akan bisa dilaksanakan. Memilih atau menemukan masalah penelitian bukan pekerjaan yang mudah, tetapi memerlukan pemikiran yang cermat dan teliti. Meskipun demikian, pada akhirnya peneliti harus menemukan masalah juga. Menemukan masalah merupakan proses yang paling rumit dalam penelitian (Creswell, 2014: 73), sehingga ada ungkapan bahwa, menemukan masalah merupakan separo dari rangkaian kegiatan penelitian (Sugiono, 2006: 76). Masalah yang dimaksud disini adalah yang benar-benar masalah, bukan masalah yang dibuat-buat. Sebab permasalahan yang dibuat-buat akan menimbulkan pemecahan yang dibuat-buat pula. Hal ini jelas bertentangan dengan kaidah keilmuan penelitian yang menghendaki adanya masalah berdasarkan data dan fakta.

Masalah dapat diartikan sebagai kesenjangan atau penyimpangan antara seharusnya dengan apa yang sebenarnya terjadi. Adapun cara untuk menemukan masalah dapat dilacak dari beberapa peristiwa, sebagaimana yang diungkapkan oleh Sugiyono (2006: 52-54), yaitu: (1) adanya penyimpangan antara pengalaman dengan kenyataan, (2) adanya penyimpangan antara apa yang telah direncanakan atau diidealkan dengan kenyataan, (3) adanya pengaduan dari berbagai pihak yang berkepentingan, dan (4) adanya kompetisi yang tidak sehat.

Tidak semua masalah penelitian yang ditemukan di lapangan layak diteliti dan memberi kontribusi yang signifikan pada pengembangan keilmuan. Ada beberapa kriteria masalah dimaksud layak diteliti, yaitu: (1) masalah harus feasible, dalam arti masalah tersebut layak diteliti dan dapat dicarikan jawabannya melalui sumber yang jelas, tidak banyak menghabiskan dana, tenaga dan waktu; (2) masalah harus jelas, yaitu semua orang memberikan persepsi yang sama terhadap masalah tersebut; (3) masalah harus signifikasn, dalam arti jawaban masalah yang diberikan harus memberikan kontribusi terhadap pengembangan keilmuan dan pemecahan masalah kehidupan manusia; dan (4) masalah bersifat etis, yaitu tidak berkenaan dengan hal-hal yang bersifat etika, moral, nilai-nilai keyakinan dan agama (Arikunto, 1992: 23-24 dan Sugiyono, 2006: 76-77).

Masalah penelitian dapat digali dari beberapa sumber. Menurut McMillan (2008: 33-35) sumber masalah penelitian paling tidak ada 4 (empat), yaitu: pengalaman dan ketertarikan para peneliti, penerapan teori, replikasi atas penelitian yang dilakukan orang sebelumnya, dan klarifikasi temuan yang kontradiktif. Lodiko, Spaulding, dan Voegtle (2010: 391-391) menyebutkan bahwa sumber masalah penelitian dari review literatur meliputi: artikel dalam jurnal profesional, laporan penelitian, paper proceding konferensi atau seminar, buku-buku referensi, monograf, buku-buku umum, tesis atau disertasi, websites, majalah atau koran, komunikasi personal (informasi dari wawancara, presentasi, dan dosen).Gay, Mills, dan Airasian (2012: 62-63) menyebutkan mengenai sumber masalah atau topik penelitian ada 5 (lima), yaitu: teori-teori, pengalaman individu, studi yang dapat direplikasi,sumber-sumber kepustakaan, dan electronic mailing lists. 
Dari beberapa pemikiran tersebut, dapat disintesiskan bahwa sumber masalah penelitian terdiri atas penerapan teori, studi yang dapat direplikasi, klarifikasi temuan yang kontradiktif, review literatur, pengalaman individu, dan electronic mailing lists. Sumber masalah ini dapat digali lebih dalam, agar dapat menemukan masalah penelitian yang aktual dan kontekstual serta relevan dengan kebutuhan pendidikan dan pembelajaran di MI.

\section{RUANG LINGKUP \& TEMA PENELITIAN PENDIDIKAN DI MADRASAH IBTIDAIYAH}

Penelitian pendidikan sebagai upaya untuk memecahkan masalah pendidikan seringkali disempitkan maknanya menjadi pembahasan tentang metode pembelajaran, dan lebih sempit lagi menjadi pemaknaan cara dan gaya mengajar di kelas. Akibatnya, penelitian pendidikan hanya sebatas pada metode mengajar, tanpa mengembangkan penelitian yang berkaitan dengan media dan sumber pembelajaran, motivasi dan retensi belajar, pengembangan bakat-minat, prestasi dan hasil belajar. Juga kurang mengapresiasi pada penelaahan mengenai lembaga pendidikan di luar sekolah dan lingkungan sosial yang memberikan kontribusi pada pengembangan pendidikan dan pembelajaran di Madrasah Ibtidaiyah. Dengan cara pandang demikian, maka satusatunya tindakan strategis madrasah adalah menghasilkan guru yang handal yang mampu melahirkan pemikiran strategis dan inovatif dalam bidang pendidikan dan pembelajaran melalui penelitian.

Menurut Bawani (2016: 391-405), obyek penelitian tentang aktifitas pembelajaran (termasuk di madrasah) banyak sekali cakupannya, seperti siswa sebagai pembelajar, guru sebagai pemandu aktifitas pembelajaran, kurikulum atau materi pembelajaran, metode pembelajaran, media pembelajaran, evaluasi pembelajaran, filsafat pembelajaran, tujuan pembelajaran, dan manajemen pembelajaran. Bukatko \& Daehler (2001: 549-560) melengkapi dengan beberapa masalah yang dapat diangkat dalam penelitian, seperti prestasi akademik dan non-akademik siswa, faktor-faktor prediktif keberhasilan akademik siswa, lingkungan fisik sekolah, filsafat pendidikan yang dikembangkan di sekolah (kelas terbuka, sekolah magnet, belajar kelompok kecil, pelacakan akademik), transisi sekolah (permulaan sekolah, perubahan kedua dan seterusnya), guru sebagai agen untuk mempengaruhi (peran yang diharapkan, strategi manajemen kelas, suasana kelas), perbedaan budaya pada prestasi sekolah (prestasi sekolah antara siswa mayoritas dan minoritas, perbedaan prestasi siswa antar daerah, dan lain-lain).

Senada dengan pemikiran tersebut, Sukmadinata (2007: 23-49) mengidentifikasi mengenai ruang lingkup penelitian pendidikan secara umun ada 5 (lima), yaitu: (1) komponen-komponen proses pendidikan (interaksi pendidikan, tujuan pendidikan, lingkungan pendidikan, pergaulan pendidikan), (2) landasan dan perbuatan mendidik (landasan psikologis, siswa sebagai individu, kemampuan dan karakteristik siswa, perkembangan siswa), (3) kurikulum dan manajemen pendidikan (manajemen pendidikan, kebijakan pendidikan), (4) teori pendidikan dan kurikulum (teori-teori pendidikan, teori kurikulum dan pembelajaran), dan (5) penelitian bidang-bidang pendidikan (penelitian bidang ilmu dan praktek pendidikan, penelitian bidang ilmu dan praktek kurikulum dan pembelajaran, penelitian bidang ilmu dan praktek bimbingan dan konseling, penelitian bidang ilmu dan praktek manajemen pendidikan). Kelima komponen tersebut masih bisa diperinci menjadi sub-sub komponen yang 


\section{MADRASAH}

Jurnal Pendidikan dan Pembelajaran Dasar

p ISSN: 1979-5599 | e ISSN: 2502-194X

dapat dijadikan tema atau masalah penelitian di Madrasah Ibtidaiyah. Misalnya untuk point 5 penelitian bidang ilmu dan praktek pendidikan, dapat dielaborasi menjadi penelitian tentang pendidikan teoritis (kajian filosofis tentang pendidikan: idealisme, realisme, pragmatisme, dan eksistensialisme), dan pendidikan praktis (berdasarkan lingkungan dan kelompok usia, berdasarkan jenjang, berdasarkan bidang studi, dan pendidikan berdasarkan jenis). Penelitian bidang ilmu dan praktek kurikulum dan pembelajaran dapat dielaborasi menjadi penelitian tentang kurikulum teoritis (teoriteori desain dan rekayasa kurikulum, teori-teori pembelajaran, teori-teori evaluasi), dan kurikulum praktis (kurikulum sebagai rencana, penyusunan kurikulum, implementasi kurikulum, evaluasi dan penyempurnaan kurikulum, dan manajemen kurikulum).

Untuk melengkapi kajian tersebut, dengan mengintrodusir pemikiran Dimyati (1988) mengenai 5 (lima) lembaga pendidikan dalam realitas eepirik sekarang, yaitu: keluarga, sekolah, lembaga agama, Pramuka, dan media massa. Lembaga pendidikan ini apabila disilangkan dengan jenis masalah yang terjadi di madrasah, akan nampak dimensi garapan penelitian pendidikan semakin luas. Hal ini mempunyai implikasi pada landasan dan struktur keilmuan pendidikan di Madrasah Ibtidaiyah. Dengan matriks silang ini, dapat dijelaskan mana bidang yang sudah banyak diteliti dan mana yang belum banyak diteliti untuk dikembangkan lebih lanjut. Matriks tersebut dapat digambarkan sebagai berikut:

Tabel D.1 Matriks Silang Jenis Permasalahan Pendidikan dengan Lembaga Pendidikan

\begin{tabular}{|c|c|c|c|c|c|}
\hline \multirow[b]{2}{*}{ Jenis Masalah } & \multicolumn{5}{|c|}{ Lembaga Pendidikan } \\
\hline & $\begin{array}{c}\text { Keluarg } \\
\text { a }\end{array}$ & $\begin{array}{l}\text { Sekolah/ } \\
\text { Madrasah }\end{array}$ & $\begin{array}{c}\text { Lembaga } \\
\text { Agama }\end{array}$ & Pramuka & Media Massa \\
\hline $\begin{array}{l}\text { Masalah } \\
\text { Landasan }\end{array}$ & & & & & \\
\hline $\begin{array}{l}\text { Masalah } \\
\text { Struktur }\end{array}$ & & & & & \\
\hline $\begin{array}{l}\text { Masalah } \\
\text { Operasional }\end{array}$ & & & & & \\
\hline
\end{tabular}

Adaptasi dari Soedomo (1992:70).

Dengan mencermati matriks tersebut, nampak bahwa kegiatan penelitian pendidikan di MI lebih tertumpu pada kegiatan operasioanal di kelas, belum menyebar pada berbagai masalah dan lembaga pendidikan. Untuk itu, yang perlu digali lebih lanjut adalah bagaimana penelitian pendidikan di MI lebih menyebar pada berbagai dimensi, sehingga nampak keluasan dan kekokohan keilmuan pendidikan dan pembelajaran. Dari matriks ini dapat diketahui kekuatan dan kekurangan penelitian Pendidikan dan pembelajaran, dilihat dari segi jenis masalah dan lembaganya. Pemetaan inilah yang seharusnya menjadi tanggungjawab Kementerian Agama sebagai amunisi untuk mengambil kebijakan dalam menyelesaikan masalah pendidikan dan pembelajaran di madrasah. Misalnya, pemetaan pada masalah struktur di madrasah. Dari sini akan diketahui, madrasah apa dan dimana pada masalah struktur (kurikulum dan kelembagaan) bagus, sehingga dapat dijadikan sebagai unggulan ? Demikian juga pemetaan pada masalah struktur dengan lembaga keagamaan. Dari sini akan diketahui 
lembaga agama mana dan jenis kegiatan apa yang dapat membentuk akhlak karimah siswa di Madrasah Ibtidaiyah ? Dengan penyilangan masalah dan lembaga tersebut, apabila dikaji lebih mendalam akan melahirkan sekian banyak masalah dan tema penelitian yang bisa dikembangkan menjadi penelitian yang berkualitas di Madrasah Ibtidaiyah.

Berangkat dari pemikiran tersebut, maka dapat disintesiskan beberapa masalah atau tema yang dapat diangkat dalam penelitian bidang pendidikan dan pembelajaran di Madrasah Ibtidaiyah. Masalah atau tema dimaksud berkaitan dengan:

1. Intra kurikuler, meliputi: kurikulum dan pembelajaran, ketrampilan mengajar guru, pengelolaan kelas, perencanaan pembelajaran, metode pembelajaran, media dan sumber pembelajaran, dan evaluasi pembelajaran.

2. Ekstra kurikuler, meliputi: pembinaan organisasi sekolah, pembinaan olah raga dan seni, Pramuka, upacara bendera, keputrian, dan sebagainya.

3. Manajemen madrasah, meliputi: perencanaan, pengorganisasian, pelaksanaan, pengawasan, dan penilaian.

4. Penciptaan suasana madrasah, meliputi: kebersihan, keindahan, dan ketertiban lingkungan madrasah, pembiasaan rasa keagamaan dan pembinaan spiritual, termasuk di dalamnya keaktifan dalam sholat jamaah, pembinaan lingkungan masyarakat di sekitar madrasah.

5. Kepemimpinan madrasah, meliputi: profesionalisme seorang pemimpin, karakteristik dan kepribadian pemimpin, karakteristik kepribadian staf atau bawahan, sangsi-sangsi atau hukuman, dan proses pengambilan keputusan.

6. Tenaga Kependidikan, meliputi: performansi dan profesionalisme, partisipasi guru dalam kegiatan madrasah, dan pola-pola tingkah laku yang dikembangkan.

7. Masalah kesiswaan, meliputi: ketertiban dan perilaku siswa, prestasi akademik dan non-akademik, motivasi dan semangat belajar, ketrampilan (skills), penyimpangan dan gangguan belajar.

8. Hubungan madrasah dengan masyarakat, meliputi: sambutan tentang program madrasah, penilaian terhadap performansi madrasah, kesamaan visi dan persepsi dalam pendidikan antara madrasah dengan stake holders, d. kesadaran tentang pentingnya pendidikan madrasah dalam era pembangunan, kepercayaan masyarakat terhadap madrasah, bantuan dan dukungan bagi pemeliharaan dan peningkatan program madrasah.

9. Hubungan madrasah dengan instansi terkait, meliputi: hubungan dengan instansi vertikal dan horizontal, hubungan dengan organisasi sosial keagamaan.

Untuk melengkapi pembahasan mengenai tema penelitian tersebut, disajikan beberapa contoh penelitian yang dilakukan di Madrasah Ibtidaiyah oleh para guru atau dosen. Misalnya penelitian yang dilakukan oleh Al Fuad dengan judul Penggunaan Media Visual Dalam Pembelajaran Bahasa Arab Di Madrasah Ibtidaiyah. Penelitian ini masuk tema pada point 1 (intra kurikuler, media pembelajaran). Hasil penelitian menunjukkan bahwa penggunaan media visual dalam pembelajaran bahasa Arab sangat efektif untuk meningkatkan pemahaman siswa terhadap Bahasa Arab dengan mudah dan cepat. Nilai rata-rata hasil belajar siswa mengalami peningkatan dari 63,3 menjadi 76,3 pada siklus I, kemudian pada siklus II menjadi 86,6. Angka ini naik secara signifikan dari sebelumnya. (Jurnal Penelitian Pendidikan, Jilid 2 Nomor 3, September 2014). 


\section{MADRASAH}

Jurnal Pendidikan dan Pembelajaran Dasar

p ISSN: 1979-5599 | e ISSN: 2502-194X

Juga penelitian yang dilakukan oleh Rofi'uddin, dkk, mengenai Pengaruh Keterampilan Komunikasi Terhadap Prestasi Belajar Aqidah Akhlak Siswa Kelas V MI Attaraqqie Kota Malang. Penelitian ini masuk tema pada point 7 (kesiswaan, ketrampilan komunikasi). Hasil penelitian menunjukkan bahwa keterampilan komunikasi siswa diperoleh dengan nilai rata-rata 69,02 dan persentase 43,90\%, sehingga menunjukkan kategori sedang. Sedangkan untuk prestasi belajar AqidahAkhlak diperoleh dengan nilai rata-rata 87,56 dan persentase 34,15\%, sehingga menunjukkan kategori rendah. Hasil analisis statistik inferensial dengan uji signifikan menunjukkan bahwa nilai 0,027, berarti kategori rendah (JPMI: Jurnal Pendidikan Madrasah Ibtidaiyah Volume 2 Nomor 1, Januari 2020).

Terakhir penelitian yang dilakukan oleh Kholil \& Usriyah mengenai Pengembangan Buku Ajar Matematika Terintegrasi Nilai-Nilai Keislaman Dalam Penanaman Karakter Siswa Madrasah Ibtidaiyah. Penelitian ini masuk tema pada point 1 (intra kurikuler, sumber pembelajaran). Hasil penelitian menunjukkan bahwa kelayakan atau kemenarikan penggunaan buku ajar matematika terintegrasi nilai-nilai keislaman sebesar $84,30 \%$. Hasil validasi atau kelayakan pengembangan produk buku ajar matematika terintegrasi nilai-nilai keislaman menunjukkan kategori sangat menarik (MADRASAH, Jurnal Pendidikan dan pembelajaran Dasar. Vol. 12, No. 1 Desember 2019).

Dengan paparan judul-judul penelitian ini diharapkan dapat menginspirasi dan memudahkan para guru MI dan mahasiswa PGMI untuk melakukan penelitian, baik penelitian untuk kepentingan pengembangan ilmu maupun penyelesaian tugas akademik. Untuk itu, kendala akademis dan psikologis yang seringkali terjadi pada diri mereka akan dapat dihindari seminimal mungkin.

\section{E. KESIMPULAN}

Pada dasarnya melakukan penelitian tidak susah, asal ada motivasi intrinsik dan ekstrinsik. Untuk itu, kepala madrasah perlu mengembangkan program strategis yang memungkinkan tumbuhnya budaya meneliti di kalangan guru MI. Masalah penelitian yang relevan dengan bidang ilmunya bisa dicari dan diperoleh dari berbagai sumber, meliputi: penerapan teori, studi yang dapat direplikasi, klarifikasi temuan yang kontradiktif, review literatur, pengalaman individu, dan electronic mailing lists. Banyak pula ruang lingkup dan tema penelitian yang dapat diformulasikan menjadi judul penelitian, meliputi: intra kurikuler, ekstra kurikuler, manajemen madrasah, penciptaan suasana madrasah, kepemimpinan madrasah, tenaga kependidikan, masalah kesiswaan, dan hubungan madrasah dengan instansi terkait.

Untuk itu, sesuatu yang harus dilakukan oleh para pengambil kebijakan di Madrasah Ibtidaiyah adalah selalu mendorong dan memfasilitasi guru untuk melakukan penelitian. Khususnya penelitian yang mampu memberikan kontribusi yang signifikan bagi peningkatan kualitas dan hasil pendidikan dan pembelajaran di Madrasah Ibtidaiyah. 


\section{REFERENSI}

Al Fuad, Z. (2014). Penggunaan Media Visual Dalam Pembelajaran Bahasa Arab Di Madrasah Ibtidaiyah. Jurnal Penelitian Pendidikan, Jilid 2 Nomor 3, September 2014, hal. 413-427.

Arikunto, S. (2991). Prosedur Penelitian, Suatu Pendekatan Praktik. Jakarta: Rineka Cipta.

Baumeister, R.F. (1999). The Self in Social Psychology. Philadelphia: Psychology Press.

Bawani, I. (2016). Metodologi Penelitian Pendidikan Islam. Sidoarjo: Khazanah Ilmu Sidoarjo, 2016.

Biehler, R.F. \& Snowman, J. (1997). Psychology Applied to Teaching. Boston: Houghton Mifflin Co.

Bukatko, D. \& Daehler, M.W. (2001). Child Development, A Thematic Approach. Boston: Houghton Mifflin Company.

Cohen, L. \& Manion, L. (1994). Research Methods in Education. Fourth Edition. London: Routledge.

Creswell, J.W. (2014). Educational Research: Planning, Conducting and Evaluating Quantitative and Qualitative Research. London: Pearson Education Limited.

Dimyati, M.(1988). Landasan Kependidikan, Suatu Pengantar Pemikiran Keilmuan Tentang Kegiatan Pendidikan. Jakarta: P2LPTK Depdikbud.

Gay, L.R., Mills, G., Airasian, P.W. (2012). Educational Research, Competencies for Analysis and Applications. New Jersey: Pearson Education, Inc.

Hasan, F. (1985). Manusia dan Citranya. Surabaya: Express.

Hopkins, D. (1985). A Teacher's Guide to Classroom Research. Philadelphia: Open University Press.

Kasiram, H.M. (1993). Petunjuk Operasional Penelitian. Makalah Lokakarya Penelitian Se IAIN Sunan Ampel dan Kopertais Wilayah IV. Malang: FT IAIN Sunan Ampel.

Kholil, M. \& Usriyah, L. (2019). Pengembangan Buku Ajar Matematika Terintegrasi Nilai-Nilai Kieslaman Dalam Penanaman Karakter Madrasah Ibtidaiyah. MADRASAH, Jurnal Pendidikan dan pembelajaran Dasar. Vol. 12, No. 1 Desember 2019, 52-62.

Lodiko, M.G., Spaulding, D.T., Voegtle, K.H. (2010). Methods in Educational Research, From Theory to Practice. San Fransico: Jossey-Bass.

Maimun, A. \& Fitri, A.Z. (2010). Madrasah Unggulan, Lembaga Pendidikan Alternatif di Era Kompetitif. Malang: UIN-MALIKI Press.

McMillan, J.H. (2008). Educational Research, Fundamentals for The Consumer. Boston: Pearson Education, Inc.

Moleong, L.J. (1990). Metodologi penelitian kualitatif. Bandung: Remaja Rosdakarya.

Mudlofir, A. (2013). Pendidik Proesional (Konsep, Strategi, dan Aplikasinya dalam Meningkatkan Mutu Pendidikan di Indonesia). Jakarta: Rajawali Pers.

Muhaimin (2016). Model Pengembangan Kurikulum \& Pembelajaran dalam Pendidikan Islam Kontemporer di Sekolah/Madrasah dan Perguruan Tinggi. Malang: UIN-MALIKI Press.

Niemi, H. \& Sihvonen, R.J. (2006). Research-Based Teacher Education. Research-Based Teacher Education In Finland: Reflection By Finnish Teacher Educators. Eds. Sihvonen, R.J.. \& Niemi, H. Turky: Paionsalama Oy. 2006: 31-50.

Oltmann, J.R., Weinstein, T.A., Oltmann, T.F. (2014). Borderline Personality Pathology and Insomnia Symptons in Community-Adults. Personality and Mental Health, $8,178-187$. 


\section{MADRASAH}

Jurnal Pendidikan dan Pembelajaran Dasar

p ISSN: 1979-5599 | e ISSN: 2502-194X

P a g e | 129

Rofi'uddin, M., Sulistiani, I.R., dan Ertanti, D.W. (2020). Pengaruh Keterampilan Komunikasi Terhadap Prestasi Belajar Aqidah Akhlak Siswa Kelas V MI Attaraqqie Kota Malang. JPMI: Jurnal Pendidikan Madrasah Ibtidaiyah Volume 2 Nomor 1, Januari 2020, 1-6.

Sardiman, A.M. (1986). Interaksi dan Motivasi Belajar Mengajar. Jakarta: CV Rajawali.

Selvi, K.. Teachers' Competencies. Cultura. International Journal of Philosophy of Culture and Axiology, vol. VII, no. 1/2010, 167-175.

Soedomo, H.M. (1992). Aktualisasi Pengembangan Ilmu Pendidikan dalam Pembangunan Nasional. Forum Penelitian, Tahun 4, Nomor 1 dan 2, Juli 1992.

Sugiyono. (2006). Metode Penelitian Pendidikan, Pendekatan Kuantitatif, Kualitatif, dan R $\mathcal{E}$ D. Bandung: Alfabeta.

Sukmadinata, N. S. (2007). Metode Penelitian Pendidikan.Bandung: PT Remaja Rosdakarya.

Sutikno, T.A. (2011). Studi Produktifitas Kerja Guru Pada Sekolah Menengah Kejuruan Negeri di Malang Raya. Jurnal Teknologi dan Kejuruan, Vol. 34 No. 1, Pebruari 2011: 1-12.

Uno, H.B., Umar, M.K., Panjaitan, K. (2014). Variabel Penelitian Dalam Pendidikan dan Pembelajaran. Jakarta: PT Ina Publikatama.

Wahidmurni \& Ali, N. (2008). Penelitian Tindakan Kelas, Pendidika Agama dan Umum, Dari Teori Menuju Praktik, Disertai Contoh Hasil Penelitian. Malang: UM Press. 